\title{
Direct and indirect effects of tidal elevation on eelgrass decomposition
}

\author{
Andrea Nicastro ${ }^{1, *}$, Yusuke Onoda ${ }^{2}$, Melanie J. Bishop ${ }^{1}$ \\ ${ }^{1}$ Department of Biological Sciences, Macquarie University, North Ryde, New South Wales 2109, Australia \\ ${ }^{2}$ Department of Biology, Kyushu University, Hakozaki 6-10-1, Fukuoka 812-8581, Japan
}

\begin{abstract}
In urbanised coastal environments, where shoreline migration is impeded by hard structures, sea-level rise is expected to impact decomposition processes by changing the patterns of tidal inundation. We assessed how tidal elevation directly (by determining the decomposition environment) and indirectly (by determining leaf traits) influences the decay of the south-east Australian seagrass Zostera muelleri. First, we assessed how the standing biomass and quality of Z. muelleri leaves varied across a tidal elevation gradient. Second, we used a litter-bag experiment to assess how the effects of tidal elevation on leaf traits and the decompositional environment interact to influence the decomposition rate. Surveys of 3 estuaries revealed that the size and stiffness of seagrass blades increased with depth, and the carbon and fibre content of blades was greater at subtidal and low intertidal zones than at high intertidal elevations. The differences in leaf traits among tidal elevations were, however, less important than the differences in aerial exposure for controlling the decomposition rate. The litter bags incubated at subtidal and low intertidal elevations had a faster rate of decomposition than those incubated in the high intertidal, irrespective of litter quality. Across elevations, the decay rates of the intertidal seagrass and the stiffer subtidal Zostera were similar. These results suggest that sea-level rise will influence decay processes by changing the decompositional environment rather than by changing tissue quality. Studies investigating differences in litter production among tidal elevations and the capacity of hydrodynamic processes to transport excess litter are now required to facilitate ecosystem-level predictions of the effects of sea-level rise.
\end{abstract}

KEY WORDS: Climate change $\cdot$ Intertidal $\cdot$ Seagrass $\cdot$ Litter bag $\cdot$ Litter quality $\cdot$ Sea-level rise

\section{INTRODUCTION}

The decomposition of plant material is a fundamental process that regulates the remineralisation of nutrients and the cycling of carbon in ecosystems (Swift et al. 1979). In many ecosystems, a large proportion $(>50 \%)$ of primary production is not consumed by herbivores but persists in the environment as dead organic matter (Cebrián \& Lartigue 2004). Some organic matter is subjected to decomposition and used by decomposers and detritivores, whereas recalcitrant components accumulate, storing carbon (Cebrián 1999). Given the relevance of the decompo- sition process to carbon cycles, understanding the factors that influence decompositional processes is of critical importance.

The rate at which litter is decomposed or accumulated is determined by the interplay among litter quality, climate and the decomposer community (Aerts 1997). The physico-chemical and material characteristics of litter, such as carbon, nitrogen and fibre content, concentration of phenolics and tissue strength, influence its decomposition rate and palatability to consumers (Enríquez et al. 1993, Cornelissen \& Thompson 1997, Hättenschwiler \& Vitousek 2000, Pérez-Harguindeguy et al. 2000, Cornwell et al. 
2008). Climate can influence decomposition rates directly by modifying the environment for decomposition and indirectly by modifying the physicochemical traits of leaves (Swift et al. 1979). Many of the biochemical reactions involved in decomposition are temperature-dependent, resulting in a tendency of decomposition rates to decrease with increasing latitude (Zhang et al. 2008). Additionally, moisture can accelerate the decompositional process by facilitating the loss of soluble compounds and influencing the activity of decomposers (Swift et al. 1979, Dick \& Osunkoya 2000), possibly explaining the observed general pattern of higher decomposition rates in aquatic systems (Cebrián \& Lartigue 2004).

By influencing the decompositional environment and litter traits, human-induced climatic change is predicted to have major impacts on decompositional processes (Davidson \& Janssens 2006). Researchers have begun to consider how warming might accelerate decomposition and how the resulting release of carbon may feedback positively to further enhance warming (Davidson \& Janssens 2006). In coastal systems, however, major changes in decompositional processes may also arise from altered patterns of tidal inundation. Although coastal ecosystems have previously survived many rises and falls in sea level (Kopp et al. 2009), the urbanisation of estuaries is replacing natural shorelines with sea walls and revetments that undermine the adaptive capacity of coastal ecosystems by impeding the landward migration of the shoreline (Bulleri \& Chapman 2010). Where shoreline migration is impeded, eustatic sealevel rise is projected to transform a large proportion of the intertidal habitat into a permanently submerged environment (Galbraith et al. 2002, Fujii \& Raffaelli 2008). So-called 'coastal squeeze', already evident in several parts of the world (Doody 2004), might directly alter decompositional processes within estuaries by transforming the intertidal environments in which autochthonous and allochthonous organic matter accumulates and decomposes into permanently submerged environments (Marinucci 1982, Twilley et al. 1986, Robertson 1988). Coastal squeeze may indirectly modify decomposition by altering the growing environment for aquatic primary producers and, by extension, the quantity and quality of autochthonous litter that they produce as well as by influencing the distribution and composition of decomposer communities.

Seagrasses are important sources of detritus in estuarine and coastal ecosystems (Heck et al. 2008). Seagrasses display high rates of primary production (1 to $18.7 \mathrm{~g} \mathrm{C} \mathrm{m}^{-2} \mathrm{~d}^{-1}$; Stevenson 1988, Dawes 1998) and in many, but not all, parts of the world (see Valentine \& Duffy 2006) are subject to little herbivory (Mateo et al. 2006). Where herbivory is low, a large fraction of seagrass biomass enters the detrital pool during seasonal senescence or during storm events that can break blades and uproot shoots. Depending on the buoyancy of the seagrass, winds and water circulation patterns, 10 to $60 \%$ of the leaf production can be exported from seagrass beds (Mateo et al. 2006). Of the exported seagrass, most washes ashore and accumulates on intertidal beaches, forming wrack banks (Kirkman \& Kendrick 1997, Ochieng \& Erftemeijer 1999, Ince et al. 2007).

Here, we investigate the direct and indirect effects of tidal inundation on the decomposition of Zostera muelleri, a major primary producer along the southeast Australian coast. In estuaries, this species extends from the upper intertidal to the shallow subtidal ( $2 \mathrm{~m}$ water depth). Across this tidal elevation gradient, the leaf length and width of $Z$. muelleri varies, with subtidal plants displaying longer and wider leaves than intertidal plants (Larkum et al. 1984). We hypothesise that the physico-chemical properties of $Z$. muelleri leaves, such as fibre content and C:N ratio, will also follow the tidal elevation gradient and that, consequently, tidal inundation will influence the $Z$. muelleri decay rate not only directly by altering the decompositional environment but also indirectly by modifying the morphology of the litter entering the detrital pool. We focus our work on urbanised Australian estuaries where seawalls are constraining the landward migration of the intertidal zone due to sealevel rise. In addition to surveys of leaf traits across tidal elevations and a litter-bag experiment, we conduct shoreline profiling to assess the area of intertidal habitat that may be lost in such environments under various scenarios of sea-level rise.

\section{MATERIALS AND METHODS}

\section{Study sites}

Assessments of how tidal elevation influences the quality of the detrital resources provided by seagrass beds in urbanised estuaries were conducted at 3 sites, each within the Sydney region (New South Wales, Australia): Careel Bay, Pittwater (3337' 06" S, $\left.151^{\circ} 19^{\prime} 36^{\prime \prime} \mathrm{E}\right) ; \quad$ Pretty Beach, Brisbane Water $\left(33^{\circ} 31^{\prime} 36^{\prime \prime} \mathrm{S}, 151^{\circ} 20^{\prime} 42^{\prime \prime} \mathrm{E}\right)$; and Budgewoi Lake, Tuggerah Lakes $\left(33^{\circ} 12^{\prime} 28^{\prime \prime} \mathrm{S}, 151^{\circ} 35^{\prime} 9^{\prime \prime} \mathrm{E}\right)$. The sites were selected based on their (1) shoreline armouring (sea-walls) that would prevent shoreward 
migration of the intertidal zone in the event of sealevel rise and (2) abundant intertidal and subtidal populations of the eelgrass Zostera muelleri. Pittwater is a tide-dominated estuary, while Brisbane Water and Tuggerah Lakes are wave-dominated (Roy et al. 2001). These estuaries ranged in size from $18.4 \mathrm{~km}^{2}$ (Pittwater) to $28.9 \mathrm{~km}^{2}$ (Brisbane Water), and each have diurnal tides with a mean range of $\sim 1.3 \mathrm{~m}$.

\section{Shoreline profiling}

In March 2009, we conducted shoreline profiling to estimate the reduction in intertidal area that could be expected under different scenarios of eustatic sealevel rise (ESLR). Although Zostera muelleri does not grow beyond $1 \mathrm{~m}$ above the mean low water level (MLWL), we considered the loss of the entire intertidal zone because it is an important habitat for the decomposition of seagrass washed in from adjacent beds. At each study site, we measured the width of the intertidal zone (defined as the horizontal distance between the mean high water level [MHWL] and the MLWL) along 5 regularly spaced transects, each separated by tens of meters. Along each transect, we identified the MHWL by locating the obvious watermark left by the last tidal cycle on the sea walls, ascertaining its elevation from Australian Bureau of Meteorology tidal observations and using a dumpy level (Lufkin X24) to determine the position of the MLWL relative to this known reference point. With the same instrument, we also assessed the position of the MHWL under possible ESLR scenarios for year 2100 of $0.3,0.5$ and $1 \mathrm{~m}$ (CSIRO 2007). We calculated the average percentage of reduction in transect length at each site under each scenario of change.

\section{Variation in Zostera muelleri foliar material}

To test the hypothesis that the Zostera muelleri leaf morphology and quality would vary across a tidal elevation gradient, we compared the leaf morphology, above-ground biomass and mechanical and chemical properties of $Z$. muelleri among 3 elevations at each of our study sites: high intertidal (MLWL $+0.9 \mathrm{~m}$ ), low intertidal (MLWL + $0.3 \mathrm{~m}$ ) and shallow subtidal (MLWL - $0.5 \mathrm{~m}$ ).

We collected entire Zostera muelleri plants for measurements of their shoot length, tensile properties and above-ground biomass in March 2009. Ten seagrass-containing cores of sediment, $100 \mathrm{~mm}$ in diameter and $200 \mathrm{~mm}$ deep, were randomly collected
1 to $10 \mathrm{~m}$ apart from each other at each of the tidal elevations at each site. Sediments were removed from the seagrass in situ by washing the contents of each core over a $0.5 \mathrm{~mm}$ sieve. The seagrasses were transported back to the laboratory in seawater to avoid loss of turgor pressure and held in aerated seawater at $20^{\circ} \mathrm{C}$ until biomechanical tests could be carried out within $36 \mathrm{~h}$ of collection. The maximal shoot length was compared among tidal elevations and sites by randomly selecting 6 undamaged shoots per core and averaging the length $( \pm 1 \mathrm{~mm})$ of the longest leaf of the selected shoots from the top of the shoot sheath to the leaf tip. Following the measurements, the material was retained for later assessment of the biomass.

Tensile tests of Zostera muelleri leaves (assessing the leaves' resistance to tearing) were carried out using a material testing machine (5542, INSTRON) equipped with pneumatic controlled clamps to hold the leaf specimens at either end during the test. The longest intact leaf of 3 randomly chosen shoots for each replicate was scraped free of epiphytes, and the width $(w)$ and thickness $(d)$ of the leaves were measured using a precision calliper $( \pm 0.01 \mathrm{~mm})$. The leaf was then placed between the clamps, and the distance between the clamps was adjusted so that the length to width ratio of the leaf was between 20 and 25 (as per Aranwela et al. 1999). The specimen was extended at a constant speed of $0.17 \mathrm{~mm} \mathrm{~s}^{-1}$, and the force $(F)$ and displacement $(\delta)$ were recorded every $0.1 \mathrm{~s}$ until the leaf broke. Trials in which the fracture occurred within $5 \mathrm{~mm}$ of the clamps were rejected because the clamping compression can cause a local weakening of the foliar tissue, resulting in an underestimation of the tensile stress of the specimen (Aranwela et al. 1999). In the case of an invalid trial, the tensile test was repeated on a leaf from a new randomly selected shoot from the same replicate to maintain a balanced experimental design. To compare the stiffness of seagrass blades among elevations, Young's modulus $(E)$ was calculated from the initial slope of the relationship between $F$ and $\delta$ using the following equation:

$$
E=\frac{F / A}{\delta / l_{0}}
$$

where $A$ and $l_{0}$ are respectively the cross-sectional area of the leaf $(w \times d)$ and the initial length of the leaf. Averaged values of the 3 measurements of $w_{1} d$ and $E$ taken within each core were used for the data analysis. Following testing, the leaves were retained and returned to the samples from which they had come for measurement of the above-ground biomass 
(the mass following drying to a constant weight at $60^{\circ} \mathrm{C}$ ).

Foliar material for neutral-detergent fibre (NDF), carbon (C) and nitrogen (N) analyses was collected between 22 and 24 May 2010 from Zostera muelleri meadows located at the same sites and positions used for the biomass and biomechanical analyses. Shortly before this sampling, the intermittently open entrance to Tuggerah Lake closed, resulting in a negligible tidal range in Budgewoi Lake, which during our previous sampling had previously been tidal. However, comparisons of other leaf traits from before to after the closure revealed that this environmental change was sufficiently recent that the eelgrass had not yet responded. Five eelgrass samples were collected at each tidal elevation and depth. Following collection, the seagrass was carefully cleaned of epiphytes using a razor blade and rinsed with deionised water to remove all other organisms. The samples were dried to a constant weight at $60^{\circ} \mathrm{C}$ and then pulverised using a stainless-steel electric mill. A subsample of $\sim 2.5 \mathrm{mg}$ was used for the determination of the total carbon and total nitrogen content using a Leco CHN-900 elemental analyser. Another subsample was used to determine the fibre content of Z. muelleri leaves.

The amount of NDF of Zostera muelleri leaves was determined following the Van Soest (1994) method with some modifications. A known amount of dried, ground leaf material ( 20 mg) was boiled for $1 \mathrm{~h}$ with $1.8 \mathrm{ml}$ of neutral detergent solution (ANKOM Technology) in a $2 \mathrm{ml}$ tube. The supernatant was removed after centrifugation at $1000 \times g$ for $5 \mathrm{~min}$. The pellet was washed with distilled water and centrifuged at $1750 \times g$. This rinsing cycle was repeated 5 times with water and lastly with acetone. The samples were desiccated at $60^{\circ} \mathrm{C}$ until they reached a constant weight and weighed. The NDF content was calculated as the difference between the initial weight and the weight after treatment with the neutral detergent.

\section{Litter-bag experiment}

We tested hypotheses about the interacting effects of the source of the foliar material and the environmental setting on the decay rate of Zostera muelleri using a litter-bag experiment (sensu Bocock \& Gilbert 1957) at Careel Bay in the Pittwater estuary. The litter bags were $150 \times 100 \mathrm{~mm}$ in area and constructed of 1 mm nylon mesh to allow colonisation by meiofauna and small macrofauna whilst limiting the loss of fragmented material (Bradford et al. 2002). Although by excluding larger detritivores, litter bags can modify decomposition rates (Bradford et al. 2002), leafshredding crabs of the size that would have been excluded by our litter bags were uncommon at our study site (mean \pm 1 standard error [SE] density: 0.33 \pm 0.19 per $10 \mathrm{~cm}$ diameter $\times 10 \mathrm{~cm}$ deep core, $\mathrm{n}=12$ ), and the crab abundance did not differ between low intertidal and subtidal elevations ( $t$-test: $t_{10}=0.88, \mathrm{p}=$ 0.41; high intertidal zone not sampled). Moreover, the abundance ( $t$-test: $t_{10}=1.26, \mathrm{p}=0.24$ ) and species richness ( $t$-test: $t_{10}=0.14, \mathrm{p}=0.89$ ) of sedimentdwelling macroinvertebrates (>500 $\mu \mathrm{m}$ diameter) was similar between low intertidal and subtidal elevations, such that any experimental artefact of the litter bags should have been similar across treatments.

The experiment had 2 fully orthogonal factors: (1) tidal elevation with 3 levels: high intertidal (MLWL + $0.9 \mathrm{~m}$; emersed for 6 to $8 \mathrm{~h}$ per tidal cycle), low intertidal (MLWL $+0.3 \mathrm{~m}$; emersed for 2 to $4 \mathrm{~h}$ per tidal cycle) and shallow subtidal (MLWL $-0.5 \mathrm{~m}$ ); and (2) litter source with 2 levels representing Zostera muelleri leaves collected from the low intertidal or shallow subtidal. A total of 25 litter bags of each litter source were deployed at each tidal elevation.

The foliar material used in the experiment was collected fresh at Careel Bay from the low intertidal and shallow subtidal elevations at which the morphological measurements had previously been collected. Zostera muelleri from the high intertidal elevation was not included in this study because it accounts for only $7 \%$ of the total biomass of this species within Pittwater and was difficult to collect in sufficient quantities for manipulation. Entire leaves were cleaned of epiphytes, towel dried and weighed into $10 \mathrm{~g}$ portions for deployment within litter bags within $24 \mathrm{~h}$ of collection. For each of the 2 plant sources, 10 samples, each of $10 \mathrm{~g}$ (wet weight), were dried to a constant weight at $60^{\circ} \mathrm{C}$ and reweighed to determine the dry- to fresh-weight conversion factors.

The litter bags were deployed on 3 September 2009, and 5 replicates for each treatment were retrieved after 5, 12, 25, 47 and $98 \mathrm{~d}$ (total $\mathrm{n}=150$ ). At each depth, the litter bags were anchored to the sediment surface using fishing line tied to plastic posts. After retrieval, the remaining plant material in the litter bags was gently rinsed with water to remove exogenous material, dried to a constant weight at $60^{\circ} \mathrm{C}$ and weighed.

The decomposition constant $k\left(\mathrm{~d}^{-1}\right)$ for each treatment of the litter-bag experiment was calculated using an exponential model (Olson 1963):

$$
x_{t}=x_{0} \mathrm{e}^{-k t}
$$


where $x_{0}$ is the amount of litter at the beginning of the experiment, and $x_{t}$ is the amount of litter after time $t$ (in days). This equation was linearised by plotting $\ln \left(x_{0} / x_{t}\right)$ versus $t$, and a linear regression with a y-intercept (i.e. dry weight at $t=0$ ) of $100 \%$ was performed to calculate the decomposition rate, $k$. The decomposition constant $k$ was used to calculate the half-life $\left(t_{1 / 2}=\ln (2) / k\right)$ of the Zostera muelleri litter (i.e. the time in days required for a reduction of half of its initial mass).

\section{Data analysis}

Differences in the morphological, biomechanical and biochemical traits of Zostera muelleri among tidal elevations and across the 3 sites were assessed using a permutational analysis of variance (PERMANOVA, PRIMER v6; Anderson et al. 2007). This non-parametric procedure uses permutations to partition the variation among individual and interaction terms, using a dissimilarity matrix as its data input (the Euclidian distances among samples, in this instance). Consequently, unlike ANOVA, PERMANOVA does not require the data to be normally distributed. The analyses had 2 orthogonal factors: (1) 'site', random with 3 levels (Careel Bay, Pretty Beach and Budgewoi Lake); and (2) 'depth', fixed with 3 levels (high intertidal [H], low intertidal [L] and subtidal [S]). Where significant differences between treatments were detected $\left(\mathrm{p}_{\text {perm }}<0.05\right)$, we ran pair-wise a posteriori tests to identify the sources of the differences.

To test the effect of the litter source and the decompositional environment on the decomposition rate of Zostera muelleri, we used PERMANOVA with 2 orthogonal factors, depth (H, L or S) and litter source (low intertidal or subtidal), and with time (i.e. Days 0 to 98) as a covariate. We used the raw values of the percentage of dry weight remaining at each sampling time to construct the dissimilarity matrix. Pairwise tests were run to identify the sources of the differences when significant differences were detected $\left(\mathrm{p}_{\text {perm }}<0.05\right)$.

\section{RESULTS}

\section{Shoreline profiling}

At Careel Bay, the average $( \pm 1 \mathrm{SE})$ reduction of the intertidal foreshore width was estimated to be $8 \pm 7 \%$ for an ESLR of $0.3 \mathrm{~m}, 49 \pm 6 \%$ for a $0.5 \mathrm{~m}$ rise and $91 \pm$
$5 \%$ for a $1.0 \mathrm{~m}$ rise. Larger reductions of the intertidal foreshore were predicted for Pretty Beach, where the average beach reduction was $32 \pm 11 \%, 69 \pm 12 \%$ and $100 \pm 5 \%$ for an ESLR of $0.3,0.5$ and $1.0 \mathrm{~m}$ respectively. The measurements indicated that Budgewoi Lake would experience no reduction with the occurrence of an ESLR of $0.3 \mathrm{~m}$ and reductions of $11 \pm 5 \%$ and $24 \pm 7 \%$ with sea-level rises of 0.5 and $1.0 \mathrm{~m}$ respectively.

\section{Variation in Zostera muelleri foliar material}

As indicated by the significant interaction term in the PERMANOVA analyses (Table 1), the magnitude of differences among depths in Zostera muelleri foliar length, width, biomass and nitrogen and fibre content varied among the sites. The leaf thickness, stiffness and carbon content, by contrast, were mainly driven by depth (Table 1). Nevertheless, within each site, the length and width of seagrass blades generally increased with water depth, as did thickness, which displayed a strong response to depth (Table 1a-c, Fig. 1a-c). Consequently, there was a positive relationship between depth and biomass within each site (Fig. 1d). The material stiffness (measured using Young's modulus) displayed a pattern of increase with depth across all of the sites (Table 1e, Fig. 1e), with statistically significant differences among each of the depths considered at each site (Student-Newman-Keuls tests, main effect of depth). The carbon and NDF content of $Z$. muelleri leaves were consistently lower in the high intertidal zone compared to the other 2 depths (Table 1f,i, Fig. $1 \mathrm{f}, \mathrm{i})$. The nitrogen content, by contrast, did not show any consistent pattern among depths across the 3 study sites (Table 1g, Fig. 1g). The C:N ratio was not influenced by depth (Table 1h, Fig. 1h).

\section{Litter-bag experiment}

The decomposition constant $(k)$ of Zostera muelleri litter followed a negative exponential decay pattern (linear regression: $\mathrm{p}<0.001$; Table 2, Fig. 2), with significant mass loss already evident by the first time of sampling ( $t=5 \mathrm{~d})$. The average half-life of $Z$. muelleri litter across all of the treatments was $53 \pm 3 \mathrm{~d}$ and ranged from $47 \pm 1 \mathrm{~d}$ in the low intertidal treatment to $62 \pm 1 \mathrm{~d}$ in the high intertidal treatment (Table 2). The rate at which $Z$. muelleri decomposed over the duration of the experiment was strongly affected by the tidal elevation at which the litter bags were incu- 
Table 1. Two-way PERMANOVA testing for spatial variation in leaf traits of Zostera muelleri among high intertidal, low intertidal and subtidal depths (Depth, D) and among 3 study sites (Site, S). (a-e): $\mathrm{n}=10$; $(\mathrm{f}-\mathrm{i}): \mathrm{n}=5$. $\mathrm{p}$-values in bold are significant at $\alpha=0.05$

\begin{tabular}{|c|c|c|c|c|}
\hline Source & $\mathrm{df}$ & MS & Pseudo- $F$ & $\mathrm{p}_{\text {perm }}$ \\
\hline \multicolumn{5}{|l|}{ (a) Length } \\
\hline Site & 2 & 66 & 7.6 & 0.002 \\
\hline Depth & 2 & 3206 & 27.5 & 0.009 \\
\hline $\mathrm{S} \times \mathrm{D}$ & 4 & 117 & 13.5 & $<0.001$ \\
\hline Residual & 81 & 9 & & \\
\hline \multicolumn{5}{|l|}{ (b) Width } \\
\hline Site & 2 & 18.4 & 211.4 & $<0.001$ \\
\hline Depth & 2 & 8.2 & 9.1 & 0.040 \\
\hline $\mathrm{S} \times \mathrm{D}$ & 4 & 0.9 & 10.4 & $<0.001$ \\
\hline Residual & 81 & 0.1 & & \\
\hline \multicolumn{5}{|c|}{ (c) Thickness } \\
\hline Site & 2 & 0.015 & 23.4 & $<0.001$ \\
\hline Depth & 2 & 0.024 & 42.8 & 0.003 \\
\hline $\mathrm{S} \times \mathrm{D}$ & 4 & 0.001 & 0.9 & 0.406 \\
\hline Residual & 81 & 0.001 & & \\
\hline \multicolumn{5}{|c|}{ (d) Above-ground biomass } \\
\hline Site & 2 & 107170 & 30.0 & 0.001 \\
\hline Depth & 2 & 658920 & 17.7 & 0.003 \\
\hline $\mathrm{S} \times \mathrm{D}$ & 4 & 37221 & 10.4 & 0.001 \\
\hline Residual & 81 & 3571 & & \\
\hline \multicolumn{5}{|c|}{ (e) Young's modulus } \\
\hline Site & 2 & 14628 & 20.9 & $<0.001$ \\
\hline Depth & 2 & 31830 & 36.4 & 0.003 \\
\hline $\mathrm{S} \times \mathrm{D}$ & 4 & 873 & 1.2 & 0.302 \\
\hline Residual & 81 & 700 & & \\
\hline \multicolumn{5}{|l|}{ (f) Carbon } \\
\hline Site & 2 & 13.5 & 15.6 & 0.001 \\
\hline Depth & 2 & 23.4 & 26.9 & 0.025 \\
\hline $\mathrm{S} \times \mathrm{D}$ & 4 & 0.9 & 1.0 & 0.417 \\
\hline Residual & 36 & 0.9 & & \\
\hline \multicolumn{5}{|c|}{ (g) Nitrogen } \\
\hline Site & 2 & 0.7 & 29.1 & 0.001 \\
\hline Depth & 2 & 0.1 & 0.8 & 0.505 \\
\hline $\mathrm{S} \times \mathrm{D}$ & 4 & 0.1 & 4.6 & 0.005 \\
\hline Residual & 36 & 0.0 & & \\
\hline \multicolumn{5}{|l|}{ (h) $\mathrm{C}: \mathrm{N}$} \\
\hline Site & 2 & 36.5 & 13.7 & 0.001 \\
\hline Depth & 2 & 1.0 & 0.1 & 0.874 \\
\hline $\mathrm{S} \times \mathrm{D}$ & 4 & 6.9 & 2.6 & 0.052 \\
\hline Residual & 36 & 2.7 & & \\
\hline \multicolumn{5}{|c|}{ (i) Neutral fibre } \\
\hline Site & 2 & 163.2 & 53.4 & 0.001 \\
\hline Depth & 2 & 152.8 & 8.7 & 0.040 \\
\hline $\mathrm{S} \times \mathrm{D}$ & 4 & 17.7 & 5.8 & 0.001 \\
\hline Residual & 36 & 3.1 & & \\
\hline
\end{tabular}

bated (PERMANOVA, pseudo- $F_{2,150}=26.6, \mathrm{p}_{\text {perm }}=$ 0.0001 ) but not by the source of the litter (PERMANOVA, pseudo- $F_{1,150}=0.08, p_{\text {perm }}=0.77$ ) or the interaction between the 2 factors (PERMANOVA, pseudo- $F_{2,150}=2.0, p_{\text {perm }}=0.14 ;$ Fig. 2 ). Among the 3 elevations of incubation, foliar material decomposed more slowly at the high intertidal level than at the low intertidal or subtidal levels (PERMANOVA, pairwise tests, $\mathrm{p}_{\text {perm }}<0.01$; Fig. 2). However, no difference was detected between the rate at which the litter decomposed at the low intertidal and subtidal depths (PERMANOVA, pair-wise tests, $p_{\text {perm }}=0.87$; Fig. 2).

\section{DISCUSSION}

Decompositional processes in terrestrial ecosystems are affected by the physical environment, the physico-chemical and mechanical traits of litter material and the decomposer community (Swift et al. 1979, Aerts 1997, Pérez-Harguindeguy et al. 2000, Cornwell et al. 2008). Consequently, we hypothesised that tidal inundation would influence the decomposition of the morphologically plastic seagrass Zostera muelleri by (1) altering blade traits and (2) altering the abiotic and biotic conditions in which decomposition occurs. Despite significant morphological variation of the seagrass across a tidal elevation gradient, our experiments failed to detect a dominant effect of within-species trait variability on decomposition rate. Instead, the decomposition rate of low intertidal and subtidal plants was determined by elevation along a tidal gradient.

Within each of the 3 estuaries, we documented distinct changes in the leaf traits of Zostera muelleri along a tidal elevation gradient extending from the

Table 2. Decomposition constant $(k)$ and half-life $\left(t_{1 / 2}\right)$ of Zostera muelleri litter collected from low intertidal (Int) and subtidal (Subt) sources and deployed at high intertidal, low intertidal and subtidal depths at Careel Bay. Estimates of $k$ and $t_{1 / 2}$ were derived separately for each treatment using linear regression analysis between time and $\ln \left(x_{0} / x_{\mathrm{t}}\right)$, where $x_{0}$ is the amount of litter at the beginning of the experiment, and $x_{t}$ is the amount of litter after time $t$ (in days). The $y$ intercept (i.e. dry weight at $t=0$ ) was forced through $100 \%$.

All regressions were significant at $\alpha=0.001 . \mathrm{n}=25$

\begin{tabular}{|lcccc|}
\hline Litter source & $\mathrm{r}^{2}$ & $k\left(\mathrm{~d}^{-1}\right)$ & $\mathrm{SE}$ & $t_{1 / 2}(\mathrm{~d})$ \\
\hline High intertidal & & & & \\
$\quad$ Int & 0.93 & 0.0112 & 0.0006 & 62 \\
$\quad$ Subt & 0.88 & 0.0112 & 0.0008 & 62 \\
Low intertidal & & & & \\
$\quad$ Int & 0.91 & 0.0152 & 0.0009 & 46 \\
$\quad$ Subt & 0.90 & 0.0143 & 0.0009 & 48 \\
Subtidal & & & & \\
$\quad$ Int & 0.88 & 0.0145 & 0.0010 & 48 \\
$\quad$ Subt & 0.87 & 0.0132 & 0.0009 & 52 \\
\hline
\end{tabular}



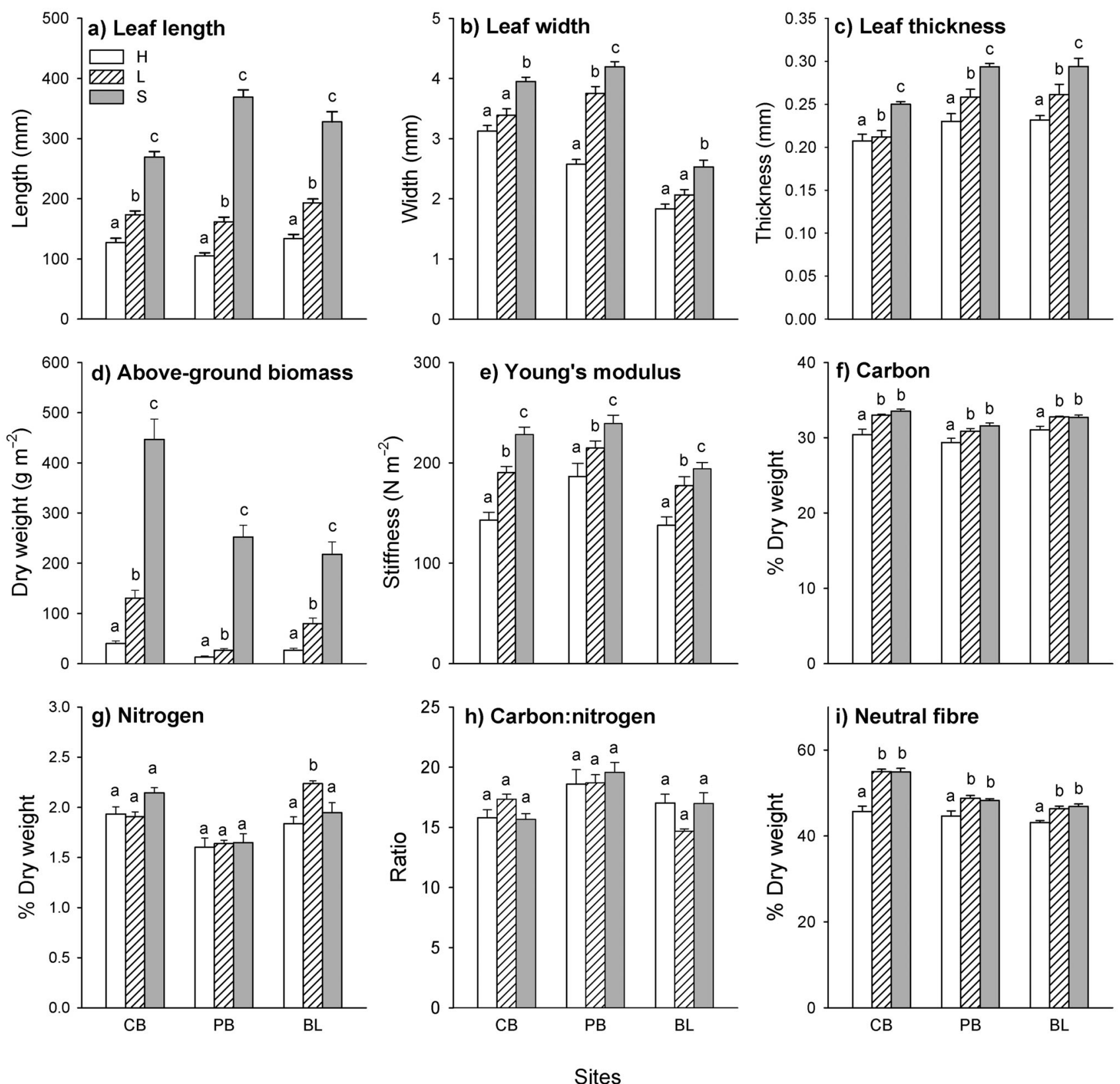

Fig. 1. Zostera muelleri. Mean $(+1 \mathrm{SE})$ values of leaf traits within high intertidal $\left(\mathrm{H}_{\text {; }}\right.$ white bars), low intertidal (L; striped bars) and subtidal ( $\mathrm{S}$; grey bars) elevations at Careel Bay (CB), Pretty Beach (PB) and Budgewoi Lake (BL). Letters denote significant (at $\alpha=0.05$ ) within-site differences among depths (post-hoc tests for significant PERMANOVA analyses; Table 1). $(\mathrm{a}-\mathrm{e}$ ): $\mathrm{n}=10$; $(\mathrm{f}-\mathrm{i}): \mathrm{n}=5$

high intertidal to the shallow subtidal. The length, width and thickness of seagrass blades each displayed a general trend of decrease with increasing tidal elevation. Additionally, the carbon and fibre contents and the stiffness of seagrass blades were lower for plants collected from the high intertidal zone than from either the low intertidal or subtidal elevations. Previous comparisons of the morphology of this species among subtidal elevations found a decrease in shoot biomass with depth, as light availability decreased (Larkum et al. 1984). We found that above a depth of $-0.5 \mathrm{~m}, Z$. muelleri showed a decrease in biomass with increasing elevation, presumably as a result of desiccation stress. Other species of Zostera have also shown marked morphological variability with respect to environmental variables, such as wave exposure, sediment properties, light availability and desiccation stress (Silva \& 


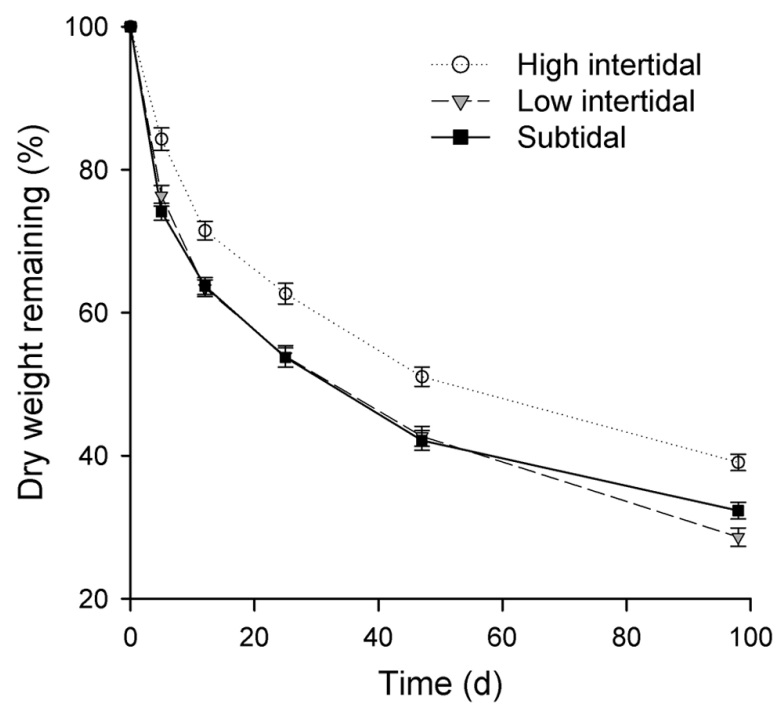

Fig. 2. Zostera muelleri. Mean ( $\pm 1 \mathrm{SE})$ percentage of the initial litter weight remaining in bags deployed at high intertidal, low intertidal and subtidal elevations on each of 5 sampling occasions. Litter sources were pooled because there was no significant difference in the decomposition of litter sourced from low intertidal or subtidal plants $\left(\right.$ PERMANOVA, $\left.\mathrm{p}_{\text {perm }}>0.05\right) . \mathrm{n}=10$

Santos 2003, Boese et al. 2005, Cabaço et al. 2009). The high morphological variability of Zostera spp. appears to be a general adaptation to tolerate a variable environment.

Despite morphological differences between the low intertidal and the subtidal morphs, their decomposition rates did not differ. The absence of a dominant effect of litter source on decomposition rate might be explained by the similar carbon, nitrogen and fibre contents of the low intertidal and the subtidal morphs used in the decomposition experiments. Among leaf traits, the total nutrient content and C:N ratio are often considered to be the most important determinants of the decomposition rate (Enríquez et al. 1993, Pérez-Harguindeguy et al. 2000, Zhang et al. 2008). According to the hypothesis that the total nutrient content and $\mathrm{C}: \mathrm{N}$ ratio are the key leaf traits influencing decomposition, the high intertidal morph, which had a lower carbon and fibre content than the other 2 morphs, might be expected to display a higher decomposition rate. The high intertidal morph was not, however, included in litter bag experiments because it did not produce enough biomass to be collected in sufficient quantities for experimentation or to significantly contribute to litter decomposition at the ecosystem level.

Tidal elevation, in contrast to leaf morphology, had a strong effect on the decomposition rate of
Zostera muelleri. Consistent with previous observations of Spartina alterniflora and mangrove leaf-litter decomposition across tidal elevation gradients (Marinucci 1982, Twilley et al. 1986, Robertson 1988, Dick \& Osunkoya 2000), we observed that the rate at which $Z$. muelleri decomposed increased with immersion time. In particular, $Z$. muelleri litter decomposing in the high intertidal had a $27 \%$ longer half-life than litter decomposing in the low intertidal and subtidal zones. The greater rate of decomposition at low intertidal and subtidal elevations may reflect a faster initial leaching of nutrients from materials that are immersed. Over the first $5 \mathrm{~d}$ of the experiment, the litter deployed in the high intertidal decomposed more slowly than the litter deployed in the low intertidal or subtidal zone (Fig. 2). After this initial period, however, the decomposition rates were similar among the 3 tidal elevations. Alternatively, a faster decomposition rate at the low intertidal and subtidal depths may reflect (1) initial retardation of microbial growth and decomposition at the high intertidal elevation by the environmentally variable conditions (Robertson 1988) or (2) differences between the high intertidal and lower elevations in micro- and meiofaunal communities, which play an important role in decomposition through ingestion and mechanical damage of decomposing plant material (Hunter et al. 2003).

Although at more exposed locations, differences in hydrodynamic conditions among tidal elevations can lead to differences in rates of the fragmentation of litter material (C. Willison pers. comm.), this mechanism is unlikely to have contributed to the differences in mass loss observed among tidal elevations in the present study. First, our experiment was conducted at an extremely sheltered estuarine site. Second, whereas the greatest differences in decomposition rates among elevations were seen early in our study, the effects of fragmentation would be expected to be more pronounced among litter that had been given more time to degrade (Bradford et al. 2002).

In the present study, litter bags were used to track the decomposition of litter material through time. Litter bags may, however, produce unrepresentative decomposition rates by (1) reducing desiccation stress in the high intertidal through enhancement of moisture retention and shading and (2) modifying the complexity of associated faunal communities (e.g. Bradford et al. 2002). At our study site, the macroinvertebrate communities of unvegetated sediments did not significantly differ between the low 
intertidal and subtidal elevations (see 'Materials and methods'). Hence, we suspect that any positive or negative artefact of macrofaunal exclusion on decomposition rates would be similar among the treatments. Moisture retention by litter bags will, however, modify environmental conditions more at high intertidal than at lower elevations. Therefore, we suspect that, if anything, our study underestimated differences in decomposition between high intertidal and lower elevations.

The shoreline profiles at each of our study sites allowed us to predict that the sea-level rise projected for the year 2100 will cause major changes in the inundation regimes in these urbanised estuaries where shoreline migration is constrained. Our sampling and experiments indicate that in the most severe cases, where the intertidal zone is severely reduced or even completely lost, a shift towards larger-bladed Zostera muelleri and a decompositional environment that accelerates decay rate may occur in temperate Australian estuaries. Whereas moderate detrital loads sustain estuarine productivity, large quantities of rapidly decomposing detritus can induce sediment anoxia and negatively affect benthic communities (Pearson \& Rosenberg 1978). Whether a shift towards larger-bladed seagrass and rapid decomposition will lead to sediment anoxia will, however, depend on the extent to which shoreline armouring reduces intertidal areas, the productivity of the seagrass, rates of herbivory and transport processes, such as currents and waves, which remove excess production from the system. Furthermore, the net outcome of sea-level rise on decompositional processes will depend on the capacity of $Z$. muelleri to adapt to changing geomorphological conditions.

Overall, this study demonstrates that the direct effects of tidal elevation on a decompositional environment are more important than the indirect effects of intraspecific variation in leaf traits in determining decomposition rates. Hence, without large shifts in litter materials from refractory to labile sources or major changes in litter supply, the main effect of sea-level rise on decompositional processes is likely to come from alteration of the decompositional environment.

Acknowledgements. We thank B. Coates and K. Michalek for help in the field and J. Madin for statistical advice. The research was funded by the Macquarie University Higher Degree Research Fund (to A.N.) and an Australian Research Council Discovery Grant DP1093444 (to M.J.B.). The comments of 4 anonymous reviewers improved the quality of the manuscript.

\section{LITERATURE CITED}

Aerts R (1997) Climate, leaf litter chemistry and leaf litter decomposition in terrestrial ecosystems: a triangular relationship. Oikos 79:439-449

Anderson MJ, Gorley RN, Clarke KR (2007) PERMANOVA+ for PRIMER: guide to software and statistical methods. PRIMER-E, Plymouth

> Aranwela N, Sanson G, Read J (1999) Methods of assessing leaf-fracture properties. New Phytol 144:369-383

Bocock KL, Gilbert OJW (1957) The disappearance of leaf litter under different woodland conditions. Plant Soil 9: 179-185

Boese BL, Robbins BD, Thursby G (2005) Desiccation is a limiting factor for eelgrass (Zostera marina L.) distribution in the intertidal zone of a northeastern Pacific (USA) estuary. Bot Mar 48:274-283

Bradford MA, Tordoff GM, Eggers T, Jones TH, Newington JE (2002) Microbiota, fauna, and mesh size interactions in litter decomposition. Oikos 99:317-323

Bulleri F, Chapman MG (2010) The introduction of coastal infrastructure as a driver of change in marine environments. J Appl Ecol 47:26-35

Cabaço S, Machas R, Santos R (2009) Individual and population plasticity of the seagrass Zostera noltii along a vertical intertidal gradient. Estuar Coast Shelf Sci 82:301-308

> Cebrián J (1999) Patterns in the fate of production in plant communities. Am Nat 154:449-468

Cebrián J, Lartigue J (2004) Patterns of herbivory and decomposition in aquatic and terrestrial ecosystems. Ecol Monogr 74:237-259

> Cornelissen JHC, Thompson K (1997) Functional leaf attributes predict litter decomposition rate in herbaceous plants. New Phytol 135:109-114

> Cornwell WK, Cornelissen JHC, Amatangelo K, Dorrepaal E and others (2008) Plant species traits are the predominant control on litter decomposition rates within biomes worldwide. Ecol Lett 11:1065-1071

CSIRO (2007) Climate change in Australia. CSIRO Marine and Atmospheric Research, Aspendale

- Davidson EA, Janssens IA (2006) Temperature sensitivity of soil carbon decomposition and feedbacks to climate change. Nature 440:165-173

Dawes CJ (1998) Marine botany, 2nd edn. Wiley \& Sons, New York, NY

> Dick TM, Osunkoya OO (2000) Influence of tidal restriction floodgates on decomposition of mangrove litter. Aquat Bot 68:273-280

Doody JP (2004) 'Coastal squeeze' — an historical perspective. J Coast Conserv 10:129-138

Enríquez S, Duarte CM, Sandjensen K (1993) Patterns in decomposition rates among photosynthetic organisms: the importance of detritus C:N:P content. Oecologia 94: $457-471$

Fujii T, Raffaelli D (2008) Sea-level rise, expected environmental changes, and responses of intertidal benthic macrofauna in the Humber estuary, UK. Mar Ecol Prog Ser 371:23-35

Galbraith H, Jones R, Park R, Clough J, Herrod-Julius S, Harrington B, Page G (2002) Global climate change and sea level rise: potential losses of intertidal habitat for shorebirds. Waterbirds 25:173-183

> Hättenschwiler S, Vitousek PM (2000) The role of polyphenols in terrestrial ecosystem nutrient cycling. Trends Ecol Evol 15:238-243 
Heck KL, Carruthers TJB, Duarte CM, Hughes AR, Kendrick G, Orth RJ, Williams SW (2008) Trophic transfers from seagrass meadows subsidize diverse marine and terrestrial consumers. Ecosystems 11:1198-1210

Hunter MD, Adl S, Pringle CM, Coleman DC (2003) Relative effects of macroinvertebrates and habitat on the chemistry of litter during decomposition. Pedobiologia 47: 101-115

Ince R, Hyndes GA, Lavery PS, Vanderklift MA (2007) Marine macrophytes directly enhance abundances of sandy beach fauna through provision of food and habitat. Estuar Coast Shelf Sci 74:77-86

Kirkman H, Kendrick G (1997) Ecological significance and commercial harvesting of drifting and beach-cast macroalgae and seagrasses in Australia: a review. J Appl Phycol 9:311-326

Kopp RE, Simons FJ, Mitrovica JX, Maloof AC, Oppenheimer $M$ (2009) Probabilistic assessment of sea level during the last interglacial stage. Nature 462:863-867

Larkum AWD, Collett LC, Williams RJ (1984) The standing stock, growth and shoot production of Zostera capricorni Aschers. in Botany Bay, New South Wales, Australia. Aquat Bot 19:307-327

Marinucci AC (1982) Trophic importance of Spartina alterniflora production and decomposition to the marshestuarine ecosystem. Biol Conserv 22:35-58

Mateo MA, Cebrian J, Dunton KH, Mutchler T (2006) Carbon flux in seagrass ecosystems. In: Larkum AWD, Orth RJ, Duarte CM (eds) Seagrasses: biology, ecology and conservation. Springer, Dordrecht, p 159-192

Ochieng CA, Erftemeijer PLA (1999) Accumulation of seagrass beach cast along the Kenyan coast: a quantitative assessment. Aquat Bot 65:221-238

Olson JS (1963) Energy storage and the balance of producers and decomposers in ecological systems. Ecology 44:

Editorial responsibility: Matthias Seaman,

Oldendorf/Luhe, Germany
322-331

Pearson TH, Rosenberg R (1978) Macrobenthic succession in relation to organic enrichment and pollution of the marine environment. Oceanogr Mar Biol Annu Rev 16: 229-311

Pérez-Harguindeguy N, Díaz S, Cornelissen JHC, Vendramini F, Cabido M, Castellanos A (2000) Chemistry and toughness predict leaf litter decomposition rates over a wide spectrum of functional types and taxa in central Argentina. Plant Soil 218:21-30

Robertson AI (1988) Decomposition of mangrove leaf litter in tropical Australia. J Exp Mar Biol Ecol 116:235-248

Roy PS, Williams RJ, Jones AR, Yassini I and others (2001) Structure and function of south-east Australian estuaries. Estuar Coast Shelf Sci 53:351-384

Silva J, Santos R (2003) Daily variation patterns in seagrass photosynthesis along a vertical gradient. Mar Ecol Prog Ser 257:37-44

Stevenson JC (1988) Comparative ecology of submersed grass beds in freshwater, estuarine, and marine environments. Limnol Oceanogr 33:867-893

Swift MJ, Heal OW, Anderson JM (1979) Decomposition in terrestrial ecosystems. Blackwell, Oxford

Twilley RR, Lugo AE, Patterson-Zucca C (1986) Litter production and turnover in basin mangrove forests in southwest Florida. Ecology 67:670-683

Valentine JF, Duffy JE (2006) The central role of grazing in seagrass ecology. In: Larkum AW, Orth RJ, Duarte CM (eds) Seagrass: biology, ecology and conservation. Springer, Dordrecht, p 463-501

Van Soest PJ (1994) Nutritional ecology of the ruminant, 2nd edn. Cornell University Press, Ithaca, NY

> Zhang DQ, Hui DF, Luo YQ, Zhou GY (2008) Rates of litter decomposition in terrestrial ecosystems: global patterns and controlling factors. J Plant Ecol 1:85-93

Submitted: June 30, 2011; Accepted: January 27, 2012

Proofs received from author(s): June 1, 2012 